\title{
Pengaruh Desain Pembelajaran Kewirausahaan terhadap Sikap Wirausaha Siswa pada SMK Negeri di Kota Makassar
}

\author{
Arniati \\ Ilmu Ekonomi dan Studi Pembangunan \\ Universitas Muhammadiyah Makassar \\ Email: arniati@unismuh.ac.id
}

\begin{abstract}
Secara empirik, pembelajaran kewirausahaan di SMK lebih berorientasi pada aspek kognitif, sehingga aspek afektif dan psiko motorik terabaikan. Permasalahan penelitianya itu bagaimana pengaruh desain pembelajaran kewirausahaan terhadap sikap wirausaha siswa pada SMK Negeri di kota Makassar dan bertujuan untuk menjelaskan pengaruh desain pembelajaran kewirausahaan terhadap sikap wirausaha siswa pada SMK Negeri di kota Makassar. Jenis penelitian ini adalah eksplanatory research menggunakan pendekatan kuantitatif dengan teknik pengumpulan data melalui wawancara dan penyebaran kuesioner analisis data metode Partial Least Square (PLS). Penelitian menunjukkan terdapat pengaruh positif dan signifikan antara desain pembelajaran kewirausahaan dengan sikap wirausaha siswa pada SMK Negeri di kota Makassar.
\end{abstract}

Kata kunci: Desain pembelajaran; sikap; wirausaha

\section{PENDAHULUAN}

Sekolah Menengah Kejuruan (SMK) sebagai salah satu lembaga pendidikan mempunyai tujuan menyiapkan lulusan siswa agar dapat bekerja secara mandiri sesuai dengan bidang dan program keahlian yang dimiliki. Untuk itu Sekolah Menengah Kejuruan (SMK), harus mampu melahirkan lulusan yang bermutu, memiliki pengetahuan, menguasai teknologi, berketerampilan teknis dan memiliki kecakapan hidup yang memadai. SMK sebagai pendidikan vokasional dituntut untuk menghasilkan tenaga-tenaga profesional yang memiliki kemampuan/kompetensi kewirausahaan, yang menjadi salah satu pilar utama aktivitas perekonomian nasional (Depdiknas,2014).

Desain pembelajaran akan memudahkan siswa mengikuti pembelajaran yang telah dirancang oleh guru. Desain pembelajaran mempermudah dalam pengorganisasian pengalaman belajar untuk mencapai tujuan belajar tertentu, dan berfungsi sebagai pedoman bagi guru dalam merencanakan dan melaksanakan aktivitas belajar mengajar. Dengan demikian, aktivitas belajar mengajar benar-benar merupakan kegiatan yang bertujuan dan tertata secara sistematik. Pengembangannya dapat juga hanya pada beberapa ranah pembelajaran, karena sifat dari materi pembelajaran. Materi pembelajaran sangat tergantung pada kebutuhan dan kemampuan anak, sehingga desain pembelajaran yang dipilih guru disesuaikan dengan kondisi lingkungan sekolah, kondisi anak dan kemampuan guru sendiri.

Sikap wirausaha kecenderungan pola tingkah laku (minat, motivasi, self concept) siswa mengenai wirausaha(Gerungan, 2000). Namun 
sikap wirausaha siswabelum diarahkan pada suatu obyek tertentu, sehingga menyulitkan dalam mengarahkan belajar siswa pada sasaran belajar yang sesuai dengan minat dan keinginannya.

Namun kondisi penyelenggaraan pendidikan terutama di SMK Negeri di kota Makassar masih berorientasi lebih mementingkan aspek kognitif dan guru yang mengajar tidak sesuai dengan kompetensinya. Para siswa di sekolah disajikan berbagai informasi secara kognitif, sedangkan aspek afektif dan psikomotoriknya praktis terabaikan. Akibat dari penyelenggaraan dan pembelajaran seperti ini, siswa tidak mempunyai sistem nilai yang dapat digunakan untuk membentuk mental dan etos kerja yang mandiri, kreatif dan inovatif. Penyelenggaraan seperti ini dalam jangka panjang siswa banyak mengetahui informasi, tetapi tidak tahu bagaimana harus bersikap dan berbuat dengan informasi dan pengetahuan yang mereka miliki. Dengan demikian permasalahan yang sering muncul dalam Pembelajaran kewirausahaan adalah bahwa Pembelajaran kewirausahaan ini disamakan desain pembelajarannya dengan pembelajaraan lainnya, tanpa menyadari bahwa pembelajaran kewirausahaan berkaitan dengan perubahan perilaku atau sikap.

Berdasarkan latar belakang penelitian di atas, maka rumusan masalah dalam penelitian ini adalah Bagaimana pengaruh desain pembelajaran kewirausahaan terhadap sikap wirausaha siswa pada SMK Negeri di kota Makassar?

Berdasarkan identifikasi masalah di atas, maka tujuan dalam penelitian ini adalah sebagai berikut:

Untuk menjelaskan pengaruh desain pembelajaran kewirausahaan terhadap sikap wirausaha siswa pada SMK Negeri di kota Makassar.

Manfaat penelitian ini, dapat diuraikan sebagai berikut :

1. Manfaat praktis

a. Sebagai bahan masukan bagi siswa dan guru pembelajaran kewirausahaan dalam meningkatkan kualitas pembelajaran, mengembangkan pembelajaran kewirausahaan yang sesuai dengan kondisi siswa serta menambah kreativitas dalam menentukan desain pembelajaran kewirausahaan.

b. Sebagai salah satu masukan bagi Sekolah Menengah Kejuruan dan dapat dikembangkan dalam pembelajaran kewirausahaan pada mata pelajaran yang lain.

2. Manfaat Teoritis

a. Dapat dipakai sebagai bahan kajian lebih mendalam bagi penelitian-penelitian lanjutan yang sifatnya lebih luas dan mendalam baik dari sisi wilayah maupun substansi permasalahannya.

b. Untuk mengembangkan ilmu pengetahuan di bidang pembelajaran kewirausahaan serta lebih mendukung teori yang telah ada sehubungan dengan masalah yang diteliti.

\section{TINJAUAN PUSTAKA Desain Pembelajaran}

Menurut Syaiful Sagala (2005) desain pembelajaran adalah sebagai proses pengembangan pengajaran secara sistematik yang digunakan secara khusus teori-teori pembelajaran unuk menjamin kualitas pembelajaran. Pernyataan tersebut mengandung arti bahwa penyusunan perencanaan pembelajaran harus sesuai dengan konsep pendidikan dan pembelajaran yang dianut dalam kurikulum yang digunakan.

Dengan demikian dapat disimpulkan desain pembelajaran adalah praktek penyusunan media teknologi komunikasi dan isi untuk membantu agar dapat terjadi transfer pengetahuan secara efektif antara guru dan peserta didik. Proses ini berisi penentuan status awal dari pemahaman peserta didik, perumusan tujuan pembelajaran, dan merancang "perlakuan" berbasis-media untuk membantu terjadinya transisi. Idealnya proses ini berdasar pada informasi dari teori belajar yang sudah teruji secara pedagogis dan dapat terjadi hanya pada siswa, dipandu oleh guru, 
atau dalam latar berbasis komunitas dengan komponen utama yaitu peserta didik, tujuan pembelajaran, strategi pembelajaran, bahan ajar dan penilaian.

Saifuddin A, (2005) mengatakan bahwa sikap adalah suatu bentuk evaluasi/reaksi terhadap suatu obyek, memihak/tidak memihak yang merupakan keteraturan tertentu dalam hal perasaan (afeksi), pemikiran (kognisi) dan predisposisi tindakan (konasi) seseorang terhadap suatu aspek di lingkungan sekitarnya.

Sikap merupakan suatu kecenderungan untuk mendekat atau menghindar, positif atau negatif terhadap berbagai keadaan sosial, apakah itu institusi, pribadi, situasi, ide, konsep dan sebagainya (Gerungan, 2000).

Gagne (2004), mengatakan bahwa sikap merupakan suatu keadaan internal (internal state) yang mempengaruhi pilihan tindakan individu terhadap beberapa obyek, pribadi, dan peristiwa.

Sejalan dengan pengertian sikap yang dijelaskan di atas, dapat dipahami bahwa: 1 . sikap ditumbuhkan dan dipelajari sepanjang perkembangan orang yang bersangkutan dalam keterkaitannya dengan obyek tertentu, 2. sikap merupakan hasil belajar manusia, sehingga sikap dapat ditumbuhkan dan dikembangkan melalui proses belajar, 3. sikap selalu berhubungan dengan obyek, sehingga tidak berdiri sendiri, 4. sikap dapat berhubungan dengan satu obyek, tetapi dapat pula berhubungan dengan sederet obyek sejenis, 5 . sikap memiliki hubungan dengan aspek motivasi dan perasaan atau emosi (Gerungan, 2000).

Menurut Bloom, serendah apapun tingkatan proses kognisi siswa dapat mempengaruhi sikap (Munandar, 1999). Namun demikian, tingkatan kognisi yang rendah mungkin saja dapat mempengaruhi sikap, tetapi sangat lemah pengaruhnya dan sikap cenderung labil. Pertanyaan yang muncul, apakah semua informasi dapat mempengaruhi sikap? Tidak semua informasi dapat mempengaruhi sikap. Informasi yang dapat mempengaruhi sikap sangat tergantung pada isi, sumber, dan media informasi yang bersangkutan.

Dilihat dari segi isi informasi, bahwa informasi yang menumbuhkan dan mengembangkan sikap adalah berisi pesan yang bersifat persuasif. Dalam pengertian, pesan yang disampaikan dalam proses komunikasi haruslah memiliki kemampuan untuk mempengaruhi keyakinan sasaran didik, meskipun sebenarnya keyakinan tersebut akan didapat siswa sendiri melalui proses belajar.

Seperti di atas telah disebutkan, bahwa untuk dapat memberikan pesan yang persuasif kepada sasaran didik haruslah dibawa pada obyek telaah melalui proses penganalisaan, pensintesisan, serta penilaian, yang dilakukan sasaran didik untuk memperoleh keyakinan. Langkah ini akan dapat berhasil manakala dilaksanaan secara individual, dan dibawa ke model belajar sambil bekerja yang selaras dengan motivasi, minat dan bakat sasaran didik.

Dengan demikian, proses belajar-mengajar klasikal, misalkan dengan ceramah, efektivitas dalam menumbuhkan sikap perlu dipertanyakan. Sumber informasi sangat berpengaruh pada penumbuhan sikap. Di samping informasi dari buku teks, mungkin juga dari fakta empirik, guru atau pendidik juga merupakan sumber belajar. Kualitas sumber informasi sangat berpengaruh pada penumbuhan keyakinan siswa. Karena itu kualitas informasi sangat menentukan perolehan pengalaman yang memadai, yang dibutuhkan untuk mengembangkan cakrawala pandang. Demikian juga fakta empirik, harus diberikan.

\section{Kerangka Pikir Penelitian}

Untuk memudahkan menganalisis dari penelitian ini, maka dibuat sebuah kerangka pikir sebagai dasar dalam pelaksanaan penelitian. 


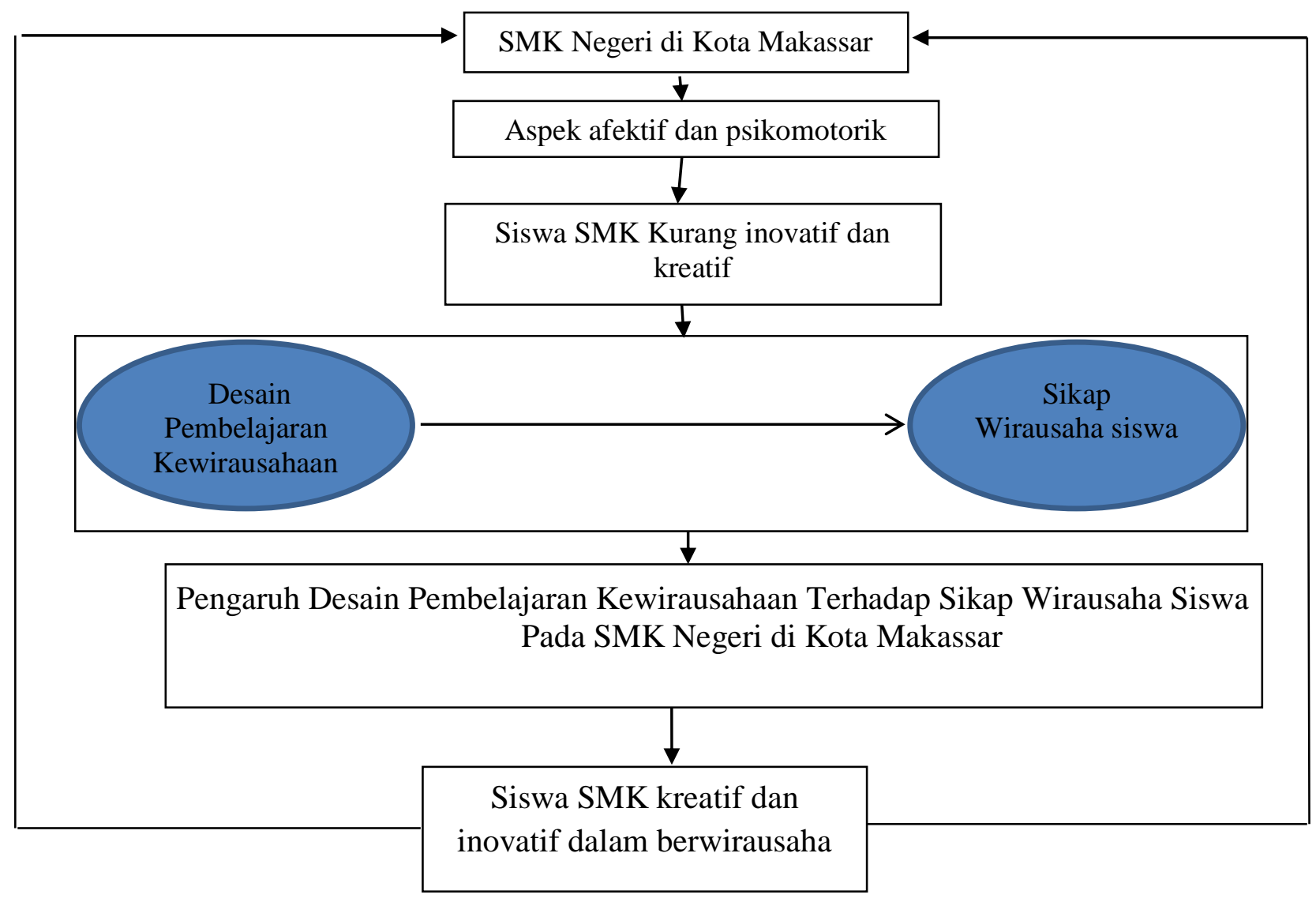

Gambar 2.1 Kerangka Pikir Penelitian

\section{METODE PENELITIAN Jenis Penelitian}

Jenis penelitian yang digunakan dalam penelitian ini adalah eksplanatory research (penelitian penjelasan) kemudian jenis data yang digunakan adalah kuantitatif, menurut Sugiyono (2011) bahwa metode kuantitatif dapat diartikan sebagai metode penelitian yang berlandaskan pada filsafat positivisme, digunakan untuk meneliti pada populasi atau sampel tertentu, pengumpulan data menggunakan instrument penelitian, analisis data bersifat kuantitatif, dengan tujuan untuk menguji hipotesis yang telah ditentukan.

\section{Defenisi Operasional Variabel}

Definisi ini sangat penting maknanya dalam memahami suatu masalah. Agar pemahaman terhadap variabel tepat dan tidak menimbulkan salah tafsir, maka dikemukakan definisi operasional variabel penelitian sebagai berikut:
1. Desain pembelajaran kewirausahaan merupakan rancangan "perlakuan" berbasis fasilitas belajar dan media film pembelajaran berupa "success story" untuk membantu terjadinya transisi yang dapat meningkatkan nilai siswa SMK dalam hal kognitif, afektif, dan psikomotorik terhadap belajar dalam mengikuti pembelajaran kewirausahaan agar dapat mempengaruhi sikap dan kompetensi wirausaha siswa SMK Negeri di kota Makassar dengan tanda-tanda yaitu tingkat keaktifan peserta didik, tujuan pembelajaran, strategi pembelajaran, bahan ajar, penilaian belajar.

2. Sikap wirausaha siswa merupakan pola tingkah laku siswa SMK mengenai wirausaha dengan indikator yaitu minat, motivasi, self concept yang diukur dengan tandatanda. 


\section{Populasi dan Sampel}

\section{Populasi}

Populasi dari 9 (sembilan) sekolah yaitu siswa kelas XII SMK Negeri di kota Makassar pada tahun ajaran 2015/2016 sebanyak 2.947 orang.

\section{Sampel Penelitian}

Populasi penelitian ini adalah siswa kelas XII SMK Negeri di Kota Makassar pada tahun ajaran 2015/2016 sebanyak 2.947 orang. Sampel penelitian ini adalah berasal dari siswa SMK Negeri di Kota Makassar dengan jumlah keseluruhan sampel sebanyak 352 orang. Analisis data dalam penelitian ini dengan menggunakan metode Partial Least Square (PLS).

\section{Teknik Pengumpulan Data}

Teknik pengumpulan data yang digunakan dengan mengumpulkan dokumen atau arsip pada SMK Negeri di kota Makassar yakni data jumlah siswa SMK, dokumentasi nilai atau hasil belajar kewirausahaan yang terdiri dari nilaipengetahuan dan praktik dan data lainnya yang mendukung penelitian ini.

\section{Instrumen Penelitian}

\section{Uji Reliabilitas}

Dalam penelitian ini, peneliti memakai kuesioner sebagai alat pengukur desain pembelajaran kewirausahaan terhadap sikap wirausaha siswa pada SMK Negeri di Kota Makassar. Sebelum dilakukan analisis, kuesioner tersebut harus diuji reliabilitas dan validitasnya terlebih dahulu. Uji Reliabilitas merupakan uji kehandalan yang bertujuan untuk mengetahui seberapa jauh alat ukur dapat dipercaya. Suatu kuesioner dikatakan reliabel atau handal jika jawaban seseorang terhadap pernyataan konstan atau stabil dari waktu ke waktu.

\section{Uji Validitas}

Uji validitas daftar pernyataan untuk mengukur sah atau valid tidaknya suatu kuesioner. Suatu kuesioner dikatakan valid jika pernyataan pada kuesioner mampu menganggap sesuatu yang diukur oleh kuesioner tersebut. Jenis validitas yang digunakan dalam penelitian ini adalah validitas konstruk, validitas konstruk diperoleh dengan menghitung korelasi antara masingmasing validitas denganscor total dengan memakai rumus correlate bivarate pearson (korelasi person) dengan program SPSS. Secara statistik angka korelasi yang diperoleh harus diuji terlebih dahulu untuk menyatakan apakah nilai korelasi yang dihasilkan signifikan atau tidak. Jika angka korelasi yang diperoleh negatif maka hal ini berkaitan dengan pernyataan lainnya dan karena itu pernyataan tersebut tidak valid atau tidak konsisten dengan pernyataan yang lain.

\section{Teknik Analisis Data}

Analisis data dalam penelitian ini dengan menggunakan metode Partial Least Square (PLS). PLS dapat digunakan pada setiap jenis skala data (nominal, ordinal, interval, dan rasio) serta syarat asumsi yang lebih fleksibel. PLS juga digunakan untuk mengukur hubungan setiap indikator dengan konstruknya. Selain itu, dalam PLS dapat dilakukan uji bootsrapping terhadap struktural model yang bersifat outer model dan inner model.

\section{HASIL DAN PEMBAHASAN}

\section{Hasil}

Hasil penelitian menunjukkan bahwa pengaruh desain pembelajaran kewirausahaan terhadap sikap wirausaha siswa SMK Negeri di kota Makassar adalah baik. Artinya, desain pembelajaran kewirausahaan layak digunakan dalam proses pembelajaran pada pembelajaran kewirausahaan di SMK karena dapat meningkatkan sikap wirausaha siswa. Hal ini didasarkan pada hasil uji coba desain pembelajaran tersebut yang merujuk pada Syaiful Sagala (2005) ditunjukkan dengan skor uji coba sebesar $37,3 \%$.

\section{Pembahasan}

Pembahasan ini dimaksudkan untuk menganalisis pengaruh antara desain pembelajaran kewirausahaan terhadap sikap 
wirausaha siswa pada SMK Negeri di Kota Makassar:

Berdasarkan hasil pengujian tersebut di atas diperoleh nilaikoefisien dalam uji jalur sebesar 0,373, diartikan bahwapembelajaran yang didesain dengan baik oleh guru dengan memberi kepercayaan kepada siswa untuk terlibat aktif dalam proses pembelajaran, sehingga siswa dapat menemukan sendiri makna atau siswa mampu mengkonstruksi sendiri pengetahuan yang telah dipelajarinya. Hal ini terwujud karena guru sebelum memasuki kelas telah mendesain pembelajaran yang ditempuh untuk melibatkan siswa secara aktif dalam belajar.

Kemudian dari hasil pengujian $t$ diperoleh nilai $\mathrm{t}_{\text {hitung }}$ sebesar 3,295, hal ini dapat disimpulkan bahwa dengan nilai $t_{\text {hitung }}$ sebesar 3,295 yang lebih besar dari 1,96 maka dapat dikatakan bahwa desain pembelajaran berpengaruh secara signifikan terhadap sikap wirausaha, sehingga dalam penelitian menemukan bahwa desain pembelajaran berpengaruh positif dan signifikan terhadap sikap wirausaha siswa SMK Negeri di kota Makassar.

\section{SIMPULAN DAN SARAN}

\section{A. Simpulan}

Desain pembelajaran kewirausahaan berpengaruh signifikan terhadap sikap wirausaha siswa karena pada desain pembelajaran kewirausahaan tidak hanya berupa kognitif saja atau penguasaan konsep tetapi juga menekankan pada penguasaan psikomotorik atau kemampuan praktek kewirausahaan dari materi yang sudah dipelajari.

\section{B. Saran-saran}

Guru mengajarkan pembelajaran kewirausahaan untuk lebih tepat dalam menyusun desain pembelajaran yang sesuai dengan bahasan dan dihubungkan dengan peristiwa sehari-hari dan mendorong siswa untuk lebih aktif dan kreatif sehingga mampu berpikir secara ilmiah dan dapat menemukan konsep-konsep pembelajaran kewirausahaan itu sendiri untuk berwirausaha sehingga berdampak terhadap sikap wirausaha siswa.

\section{DAFTAR RUJUKAN}

Fahmi, Irham. 2013. Kewirausahaan Teori, Kasus dan Solusi, cetakan kesatu,Penerbit : Alfabeta, Bandung

Gagne, R. M. 2004. The Conditions of Learning and Theory of Instruction ( $4^{\text {th }}$ ed). New York: Holt, Rinehart and Winston

Gagnon, G.W. dan Collay,M.2001. Designing for learning: Six Elements in Constructivist Classroom. California: Corwin Press.Inc.

Meredith, G.C., et.al. 2005.Kewirausahaan Teori dan Praktek, cetakan kedelapan, terjemahan Andre Asparsayogi \& Djarot Suseno), Geneva: International Labour Organization.

Munandar. 1999. Mengembangkan Bakat dan Kreativitas Anak Sekolah, Jakarta: Gramedia.

Saiman, Leonardus. 2014.Kewirausahaan Teori, Praktik, dan Kasus-Kasus, edisi kedua, Jakarta: Salemba Empat,

Aurora A.C. Teixeira (2010), Attitudes of Higher education Students to new Venture Creation : The Relevance of Competencies and Contextual Factors. Industri \& Higher Education, Vol. 24 No. 5 Oktober, 2010.

Chao-ching Chen, Yu-Fen Chen, Ming- Chuan Lai (2013) A Study on Entrepreneurial Attitude and the Influential Factors for Business Department Students in Technological Colleges/Universities in Taiwan.

Fiet, J. O. (2000) The Role of Entrepreneurship Educators on The Higher Education Institutions Students Entrepreneurial 
Competencies in Developing Countries.

Gary Packham, Paul Jones, Christopher Miller, David Pickernell and Brychan Thomas (2010) Attitudes towards entreprenurship education: a comparative analysis. The Current issue and full text archive of this journal is available. Business scholl, University of Glamorgan, Pontypridd United Kingdom.

Kissi Ernest, Somiah K. Mattew, dan Ansah K. Samuel (2015), Towards Entrepreneurial Learning Competencies: The Perspective of Built Environment Students. 